\title{
Program Intervensi Kembali Bersekolah Anak Usia Dini Masa Pandemi Covid-19
}

\author{
Jhoni Warmansyah ${ }^{凶}$ \\ Pendidikan Islam Anak Usia Dini, Institut Agama Islam Negeri Batusangkar \\ DOI: $10.31004 /$ obsesi.v5i1.573
}

\begin{abstract}
Abstrak
Berdiam diri di rumah dalam waktu yang lama sebagai upaya pencegahan dari Covid-19 menyebabkan banyak masalah pada anak-anak diseluruh dunia baik kesehatan fisik maupun mental. Penelitian ini mengkaji berbagai literatur tentang dampak penutupan sekolah dan pemberdayaan melalui program intervensi kembali bersekolah. Dengan menggunakan kajian kepustakaan, peneliti menggali data-data dari berbagai literatur yang ada untuk memecahkan suatu masalah. Hasil kajian yang diperoleh adalah dampak dari Isolasi berkepanjangan akibat dari pandemi Covid 19 menyebabkan stres tinggi dan konsekuensi psikologis pada anak-anak. Saat pandemi Covid 19 berakhir, sekolah memiliki peran yang paling krusial dalam mengembalikan dampak psikologis yang telah terjadi pasca penutupan sekolah. Strategi Koping dan membangun ketahanan adalah suatu upaya yang dapat dilakukan untuk mengurangi dampak stres yang diakibatkan oleh berdiam diri di rumah dalam waktu yang lama. Program intervensi memberikan dampak positif kepada anak terutama anak yang paling beresiko dengan status sosial-ekonomi rendah. Guru memiliki peran penting dalam pengaturan kelas dan membawa siswa kembali ke kondisi pembelajaran normal.
\end{abstract}

Kata Kunci: penutupan sekolah; program intervensi; kembali bersekolah; covid 19

\begin{abstract}
Stay at home for a long time as a preventive effort of COVID-19 causes many problems in children around the world both physical and mental health. The study examines a variety of literature on the impact of school closure and empowerment through a re-school intervention program. By using library research, researchers dig into the data of various literature to solve a problem. The results of the studies gained are the impact of prolonged isolation from the COVID 19 pandemic causing high stress and psychological consequences in children. When the COVID 19 pandemic ended, the school had the most crucial role in restoring the psychological impact that had occurred after the closure of the school. The strategy of Koping with and building resiliensi is an effort that can be done to reduce the impact of stress caused by stay at home. The intervention Program has a positive impact to students especially the children who are most at risk with low socio-economic status. Teachers play an important role in classroom settings and bring students back to normal learning conditions.
\end{abstract}

Keywords: school closure; interventional program; back to school; covid 19

Copyright (c) 2020 Jhoni Warmansyah

$\triangle$ Corresponding author:

Email Address : jhoniwarmansyah@iainbatusangkar.ac.id (Padang, Sumatera Barat, Indonesia)

Received 31 May 2020, Accepted 4 August 2020, Published 15 August 2020 


\section{PENDAHULUAN}

Pandemi Covid-19 yang telah menyebar hampir di berbagai negara menyebabkan krisis terkait masalah kesehatan dan kesejahteraan umum di seluruh dunia. Meskipun banyak studi dan para ahli menemukan anak-anak memiliki risiko yang rendah atau kurang rentan terinfeksi dan tertular oleh Coronavirus dibandingkan orang dewasa (Hong et al., 2020), akan tetapi anak-anak mungkin lebih lemah atau rapuh dari sudut pandang psikologis (Jiao et al., 2020) dan saat ini, konsekuensi yang dirasakan anak-anak dari isolasi yang berkepanjangan dirumah memiliki dampak kepada tingkat kecemasan, masalah perilaku, dan ketakutan yang tinggi. Akibatnya, para ahli atau profesional di bidang kesehatan mental (Psikologi) menyarankan bahwa intervensi spesifik perlu dilakukan selama pandemi untuk mengatasi dampak permasalahan tersebut (Liu et al., 2020), dan perlunya peningkatan komunikasi intensif antara guru dengan anak-anak karena mereka diharuskan tinggal di rumah bersama keluarga mereka (Dalton et al., 2020).

Hal tersebut senada dengan temuan penelitian yang dilakukan oleh (Wiresti, 2021), menemukan bahwa akibat pandemi covid 19, ketahanan ekonomi keluarga menjadi menurun karena banyak usaha dari orangtua yang turun omsetnya, bahkan harus gulung tikar, banyak karyawan yang dirumahkan dan di PHK sehingga memunculkan berbagai dampak baik psikologis, dan kesehatan anak diantaranya anak mengalami emosi yang tidak stabil karena harus belajar dengan orangtua dirumah yang sudah terhimpit masalah ekonomi, krisis kesehatan karena anak kekurangan gizi, adanya gap dalam pembelajaran, terjadi krisis pengasuhan dimana orang tua mengalami stress dalam membelajarkan anakanaknya. Dalam penelitian lain disebutkan bahwa kebijakan Pembatasan Sosial Berskala Besar (PSBB) mengakibatkan kuantitas waktu kebersamaan (keintiman) orangtua-anak dirumah menjadi lebih banyak dari harihari sebelumnya. Namun, dampak negatifnya yaitu sering terjadi ketidakpatuhan anak kepada orangtua karena terlalu di paksa untuk terus belajar sehingga bentrok orang tua-anak karena orang tua stress dalam mengasuh dan membelajarkan anak (Permatasari et al., 2021).

Kondisi dari intervensi yang telah diusulkan pada saat ini berfokus pada fase penguncian atau pencegahan pandemi agar tidak terjadi penularan yang masif di kalangan anak, hal tersebut juga akan berlaku ketika pandemi Covid 19 ini segera berakhir dan anakanak mulai kembali ke taman kanak-kanak, sehingga fase ini menjadi krusial yang akan memainkan peran penting dalam hal kesejahteraan mental anak-anak (Sandoval, 2013). Sebuah penelitian yang mengkaji tentang peran seoramg ibu dalam menemani anak selama masa pembatasan sosial berskala besar (phsycal distancing) menemukan bahwa terdapat dampak positif dari kebersamaan ibu yang menjadi lebih banyak waktu dirumah terutama ibu yang bekerja, namun disisi lain efek negatif juga dirasakan oleh anak karena kebosan saat dirumah saja sehingga anak menjadi rewel, susah diatur, rindu dengan suasana sekolahnya. Dampak yag lain Ibu merasakan jenuh lelah, dan memiliki tingkat kesabaran yang kurang, karena tuntutan pekerjaan lain yang harus diurus selain anak (Sari et al., 2021).

Pedoman intervensi dalam konteks pendidikan dapat diadaptasi dari berbagai literatur penanganan krisis pasca penutupan sekolah akibat dari pandemi (Jimerson et al., 2015; Sandoval, 2013). Seperti pedoman intervensi yang dibuat oleh (Capurso et al., 2020), pedoman tersebut berupa satu set lembar kerja dan materi pelatihan lainnya yang khusus dibuat untuk pandemi COVID-19. Para guru dapat memanfaatkan dan menggunakan pedoman tersebut untuk merencanakan program masuk kembali kesekolah yang konsisten untuk dijalankan ketika sekolah memulai kembali pada akhir krisis kesehatan.

Berdasarkan pada keputusan bersama beberapa kementerian terkait seperti Kemendikbud, Kemenag, Kemenkes, dan Kemendagri yang ditetapkan tanggal 15 Juni 2020 yang berisi tentang panduan sistem pembelajaran dalam jaringan (Daring) pada tahun ajaran baru pada PAUD yang akan tetap dilanjutkan dengan berbagai pertimbangan. Sementara bagi lembaga PAUD yang telah memiliki kesiapan dalam membelajarkan siswa secara tatap muka paling cepat dilaksanakan pada bulan November 2020 dan harus berada 
DOI: 10.31004/obsesi.v5i1.573

pada zona hijau/aman, serta tetap mematuhi protokol kesehatan yang ditetapkan pemerintah. Pelaksanaan tersebut dilakukan dengan bertahap, yang dimulai dua bulan selama masa transisi, dan terus dilihat perkembangannya apabila menunjukkan kondisi dan situasi yang kondusif untuk belajar paling cepat bulan Januari 2021 akan dimulai kebiasaan baru pada seluruh lembaga PAUD demi mencegah penyebaran cluster Covid-19 di sekolahsekolah. Oleh kerana itu yang belum diketahui bagaimana program intervensi kembali bersekolah dan upaya yang dapat dilakukan dalam mengatasi dampak penutupan sekolah dalam masa pandemi Covid 19.

Terkait dengan situasi dan kondisi pandemi saat ini, penelitian kepustakaan ini dimulai dengan mengkaji dampak stres masa kanak-kanak, strategi Koping dan membangun ketahanan (resiliensi) serta program intervensi yang dapat dilakukan guru saat pandemi Covid 19 berakhir. Pada akhirnya, kajian pustaka ini dapat menjadi tambahan pengetahuan tentang dampak penutupan sekolah dan prinsip-prinsip intervensi berbasis sekolah dalam program kembali bersekolah yang terbukti efektif di masa lalu, serta dapat diimplementasikan dalam pengaturan di taman kanak-kanak.

\section{METODOLOGI}

Penelitian ini menggunakan studi kepustakaan (library research), yang membatasi kegiatan pada bahan-bahan koleksi perpustakaan (Danandjaja, 2014). Penelitian kepustakaan (library research), adalah suatu metode pengumpulan data-data penelitian yang bersifat kepustakaan yang berkaitan dengan sasaran penelitian, atau dengan kata lain penelitian bibiliografi secara sistematis ilmiah yang bertujuan untuk pemecahan suatu masalah (Anwar, 2016).

Penelitian kepustakaan termasuk kedalam penelitian kualitatif. Penelaahan bahanbahan pustaka sebelum dikaji, terlebih dahulu peneliti harus mengetahui dan menganalisis secara dalam dari mana sumber informasi ilmiah yang akan digunakan. Adapun sumber data kajian kepustakaan ini berupa buku-buku dan literatur yang relevan dengan pembahasan diantaranya artikel ilmiah, majalah, surat kabar/berita maupaun hasil-hasil penelitian skripsi, tesis, desertasi, dan dan berita online terpercaya yang ada diinternet.

Adapun langkah-langkahyang menjadi pedoman pada kajian pustaka ini yaitu (Nasution, 2017).

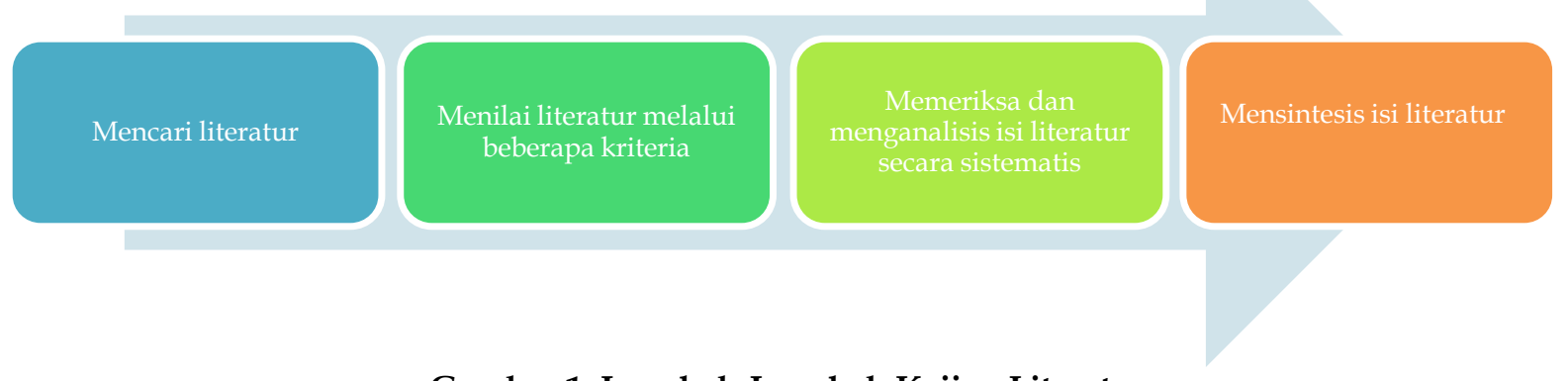

\section{Gambar 1. Langkah-Langkah Kajian Literatur}

Alasan penggunaan penelitian pustaka yaitu menjawab persoalan-persoalan penelitian dilapangan melalui studi pendahuluan sehingga mendapatkan pemahaman yang mendalamdari gejala/fenomena baru yang berkembang di tengah-tengan masyarakat atau lapangan, serta data-data pustaka yang terkumpul andal untuk menjawab persoalanpersoalan penelitian yang ada. Dengan demikan, penelitian kepustakaaan (libraray research) dapat mengkaji berbagai sumber lireratur kepustakaan yang ada guna mendapatkan datdata penelitian yang relevan dengan pembatasan pencarian sumber hanya pada bahanbahan koleksi perpustakaan tanpa memerlukan riset lapangan. 


\section{HASIL DAN PEMBAHASAN}

\section{Pandemi Covid 19 dan Penutupan Sekolah}

Dampak pandemi virus Corona 2019 (Covid-19) kini mulai menyebar ke dunia pendidikan. Hal ini dilakukan sebagai upaya untuk mencegah penyebaran Covid-19. Diharapkan bahwa semua lembaga pendidikan tidak akan melakukan kegiatan seperti biasa, ini dapat menghambat penyebaran Covid-19. Hal yang sama telah dilakukan oleh berbagai negara yang terkena penyakit ini, kebijakan penguncian atau karantina dilakukan dalam upaya untuk mengurangi interaksi banyak orang yang dapat memberikan akses ke penyebaran Covid-19 (Abidah et al., 2020).

Penyebaran Covid-19 memiliki efek mendalam pada dunia ekonomi yang mulai memudar, tetapi sekarang dampaknya dirasakan oleh dunia pendidikan. Kebijakan yang diambil oleh banyak negara termasuk Indonesia dengan menolak semua kegiatan pendidikan membuat pemerintah dan lembaga terkait harus menyajikan proses pendidikan alternatif bagi siswa dan siswa yang tidak dapat melakukan proses pendidikan di lembaga Pendidikan (Mailizar et al., 2020).

Pada 11 Maret 2020 , Organisasi Kesehatan Dunia (WHO) mendeklarasikan pandemi COVID-19. Infeksi oleh coronavirus novel bernama SARS-CoV-2 (Severe Acute Respiratory Syndrome Coronavirus-2) dapat menyebabkan penyakit bernama COVID-19 (Pedersen \& Ho, 2020)). Kasus-kasus pertama COVID-19 diamati pada Desember 2019 di kota Wuhan, Cina (Chen et al., 2020). Dengan cepat, penyakit ini menyebar ke seluruh dunia, dan, pada 28 April 2020, penyakit ini telah mencapai lebih dari tiga juta orang (CSSE, 2020). Penyebaran COVID-19 terjadi melalui tetesan yang dikeluarkan dengan berbicara, batuk, atau bersin oleh orang yang terinfeksi (WHO, 2020). Untuk mengatasi pandemi, WHO telah mengeluarkan aturan tentang prosedur kebersihan pribadi dan langkah-langkah ketat jarak social (social distancing) (WHO, 2020). Sebagai akibatnya, beberapa negara telah memerintahkan penutupan secara umum, termasuk penutupan seluruh industri, bisnis, tempat-tempat sosial dan rekreasi, dan sekolah.

Berdasarkan data yang diperoleh dari UNESCO, lebih dari 160 negara telah menerapkan penutupan nasional, mempengaruhi lebih dari setengah populasi siswa dunia. Statistik terbaru dari UNESCO (25/03/2020) menyebutkan bahwa 1.524.648.768 siswa dipengaruhi oleh virus covid-19 dari 87,1\% dari total siswa yang terdaftar. Sejauh ini India dan Cina memiliki jumlah siswa terbanyak yang terkena virus covid-19, yaitu lebih dari 270 juta siswa, dan di Indonesia per Rabu (25/3) sebanyak 68.265.787 siswa yang terkena Covid19 (UNESCO, 2020). Sementara negara-negara lain, negara-negara di Afrika, Asia, Eropa, Timur Tengah, Amerika Utara, dan Amerika Selatan telah mengumumkan atau memberlakukan pembatasan pada pembelajaran sekolah dan universitas. UNESCO memberikan dukungan langsung ke negara-negara, termasuk solusi untuk pembelajaran jarak jauh yang inklusif. UNESCO bersama dengan masing-masing negara bekerja bersama untuk memastikan kesinambungan pembelajaran bagi semua, terutama anak-anak dan remaja yang kurang beruntung yang cenderung paling terpukul oleh penutupan sekolah (UNESCO, 2020).

Sejak penemuan kasus pertama Covid 19 di Indonesia pada tanggal 2 Maret penyebaran penularan virus terus berlangsung hingga saat ini 30/5, sudah menembus pada angka 26 ribu lebih penduduk Indonesia tertular oleh wabah tersebut (Gugus Tugas Nasional, 2020; Nuraini, 2020). Penyebaran yang begitu masif menyebabkan pemerintah Indonesia sampai saat ini belum mengubah kebijakan tentang pembelajaran daring atau jarak jauh yang dilaksanakan oleh setiap lembaga pendidikan mulai dari PAUD sampai perguruan tinggi tanpa kecuali, sehingga memunculkan kekagetan budaya dan masalah dalam proses belajar di sekolah (Agustin et al., 2021). Kepala sekolah harus membuat suatu strategi yang tepat guna proses pendidikan di lembaganya dapat berlangsung dengan baik dan tetap terjaga mutu kualitas pembelajaran yang diberikan oleh guru kepada anak didiknya (Sudrajat et al., 2021). 
DOI: 10.31004/obsesi.v5i1.573

Walaupun terdapat wacana sekolah akan dimulai atau di buka kembali pada bulan Juli namun menteri pendidikan Indonesia masih mempertimbangkan situasi terus berkembang dan berubah dengan terus berkoordinasi dengan gugus tugas nasional Republik Indonesia (Prodjo, 2020). Hal tersebut menyebabkan ketidakpastian dan kecemasan tambahan dikalangan orangtua dan penyelenggara pendidikan. Isolasi fisik yang begitu lama dan gangguan kehidupan sosial yang terhubung ke sekolah merupakan penyebab keprihatinan besar terkait dengan tingkat stres dan konsekuensinya pada anakanak.

\section{Stres, Trauma, dan Mengatasi pada Anak Karantina sebagai Stresor untuk Anak-anak}

Pandemi saat ini masih berkembang dan berlangsung, belum ada hasil yang pasti, tetapi bukti awal menunjukkan bahwa karantina yang terkait dengan pandemi COVID-19 memiliki efek negatif pada kehidupan anak-anak. Sebuah penelitian survei baru-baru ini di Negara Spanyol yang dilakukan (Orgilés et al., 2020), terhadap 1.143 responden orangtua. Hasil penelitian menunjukkan bahwa $86 \%$ responden melaporkan perubahan dalam perilaku anak-anak mereka dan ekspresi emosi selama karantina, termasuk kesulitan berkonsentrasi, kebosanan, lekas marah, gelisah, kesepian, ketidaknyamanan, dan ekspresi kekhawatiran. Hasil serupa telah ditemukan di negara lain seperti Italia (Pisano et al., 2020) dan Cina (Jiao et al., 2020). Isolasi berkepanjangan yang terhubung dengan pandemi menyebabkan stres tinggi dan konsekuensi psikologis pada anak-anak.

Penelitian terbaru yang dilakukan oleh (Humphreys et al., 2020), menyebutkan dampak yang diakibatkan oleh pandemi COVID 19 adalah terjadi peningkatan risiko paparan anak terhadap kekerasan keluarga selama periode krisis. Tekanan tambahan terjadi pada orang tua yang terus bekerja penuh waktu selama periode krisis ini. Jika orang tua harus meninggalkan rumah untuk bekerja, anak-anak menghadapi peningkatan risiko untuk pengabaian pengawasan. Sebaliknya, jika bekerja dari rumah, orang tua dipaksa untuk mencoba memenuhi tuntutan pekerjaan sambil secara bersamaan merawat/mendidik anakanak mereka. Perubahan dalam rutinitas mengecewakan, membingungkan, dan sulit bagi anak. Peningkatan perilaku bermasalah kemungkinan besar akan mendapat tanggapan keras dari orang tua. Ditambah dengan kecemasan orangtua dan stres tentang masalah keuangan, logistik, dan eksistensial, interaksi ini kemungkinan merupakan pemicu untuk ledakan emosi dan pelecehan verbal dan fisik pada anak.

\section{Stres dan Karakteristiknya pada Anak}

Stres didefinisikan sebagai "respons non-spesifik dari tubuh terhadap permintaan perubahan" (Lumban Gaol, 2016). Adaptasi terhadap stres dan kesulitan adalah kunci perkembangan manusia dan fungsi penting dari tubuh manusia (de Kloet \& Molendijk, 2016). Yaitu, ketika menghadapi stres, manusia menilai hubungan antara mereka dan lingkungan sebagai beban atau melebihi sumber daya mereka. Sebagai akibatnya, stres dihubungkan dengan penilaian subyektif dari kemampuan seseorang untuk menanggapi rangsangan yang berasal dari perubahan dalam lingkungan, yang disebut "stresor" (Leger et al., 2016). Kemampuan untuk menilai dan merespons situasi stres dimoderasi oleh tingkat perkembangan kognitif dan emosional seseorang. Untuk anak-anak dan remaja, cara-cara mereka memahami dan bereaksi terhadap peristiwa-peristiwa yang penuh tekanan tergantung pada tingkat paparan, usia, jenis kelamin, fungsi psikologis, kepribadian, budaya pendukung, dan lingkungan, termasuk pengaruh orang terdekat (Dube \& McGiboney, 2018). Anak-anak terbiasa mengandalkan orang dewasa dan orang-orang yang berpengaruh lainnya untuk memenuhi kebutuhan utama mereka (Shaffer \& Kipp, n.d.). Anak-anak memproses kenyataan dengan mengandalkan emosi yang ditransmisikan oleh orang dewasa yang mengasuh/merawat mereka, sebuah proses yang disebut penularan emosi (Coyne et al., 2020). 
Untuk memahami reaksi anak-anak dalam menghadapi peristiwa-peristiwa kritis, dapat dilihat dari perkembangan anak sebagai subjek yang aktif dan dinamis selalu mengalami perubahan dalam hubungan dengan lingkungannya secara terusmenerus (Lingiardi \& McWilliams, 2017). Mayoritas anak-anak cenderung hanya menampakkan efek psikologis yang ringan dan sementara termasuk dalam menanggapi pengalaman yang intens. Namun, dalam beberapa kasus paparan stres yang berkepanjangan atau tidak terkelola dapat menyebabkan konsekuensi psikopatologis (misalnya, depresi, gangguan perilaku, gangguan kecemasan, dan gangguan stres pasca-trauma) (Danese et al., 2020). Oleh sebab itu, jika guru merasakan perubahan negatif yang terus-menerus dalam perilaku anak atau ekspresi emosional, mereka harus mendiskusikannya dengan keluarga dan bersama-sama mengevaluasi apakah akan mencari bantuan psikolog profesional. Intervensi klinis biasanya dapat mengurangi dampak traumatis, membantu dalam pemulihan, dan membawa anak kembali ke tingkat fungsi akademik, sosial, dan emosional yang sehat (L. A. Theodore, 2016).

\section{Strategi Koping dan Membangun Ketahanan (Resiliensi) pada Anak}

Strategi yang di terapkan untuk mengelola dan beradaptasi dengan lingkungan dan situasi yang penuh tekanan dan selalu berubah disebut koping (Lazarus \& Folkman, 1984). Koping adalah proses aktif di mana serangkaian tindakan, dilaksanakan melalui strategi kognitif, emosional, dan perilaku, ditempatkan untuk beradaptasi dengan, mengubah, atau mengelola stresor internal atau eksternal (Compas et al., 2012). Oleh karena itu, koping dapat terhubung dengan ketahanan (resiliensi) seseorang yaitu, kapasitas individu untuk mengembalikan stabilitas keadaan selama atau setelah paparan pengalaman buruk yang berpotensi mengganggu atau mngacaukan keberhasilan fungsi atau pengembangannya (Masten et al., 2018).

Baik koping dan ketahanan melayani perkembangan manusia karena mereka membantu individu untuk menghadapi kesulitan (Leipold \& Greve, 2009), dan dapat dibentuk dan kembangkan di masa usia dini, jika orang tua dan pendidik memberikan dukunga kepercayaan, otonomi, identitas, dan agensi kepada anak. Konsep Koping dan resiliensi memiliki relevansi khusus untuk guru dengan mengalihkan fokus perhatian dari stresor ke respons individu, dapat membuka beberapa area untuk intervensi pendidikan. Dengan demikian, penelitian telah menunjukkan bahwa intervensi kelompok berbasis sekolah, termasuk kegiatan pemrosesan trauma, permainan kooperatif, dan elemenelemen kreatif-ekspresif yang disampaikan oleh pendidik yang terlatih, dapat efektif dalam mengurangi risiko gangguan stres pasca-trauma dan hasil penting lainnya pada anak-anak (Tol et al., 2016).

Ketika sekolah kembali dimulai setelah krisis Covid-19, banyak pendidik akan merasakan kebutuhan dan keinginan yang mendesak untuk "mengambil apa yang tertinggal." Dengan demikian, guru akan berupaya memulihkan program-program yang terbengkalai karena penutupan sekolah untuk masa belajar yang hilang. Sikap seperti itu merupakan respons yang wajar terhadap stres dan kecemasan berkepanjangan dimana kita semua hidup selama isolasi.

Sebaliknya, peran yang paling menentukan untuk fase memulai kembali ke kelas bersama dengan anak-anak adalah membantu mereka membangun perasaan nyaman dan tenang terlebih dahulu dari apa yang telah terjadi dan merekonstruksi jaringan sosial dan perkembangan mereka dalam sistem sekolah (Sandoval, 2013; L. A. Theodore, 2016). Artinya, tugas pendidikan yang terpenting dari sekolah adalah melanjutkan kegiatannya setelah pandemi COVID-19 bukan hanya untuk memenuhi kurikulum, tetapi untuk meletakkan dasar kognitif dan sosial yang dapat dibangun kembali untuk masa depan (Losoya et al., 2014). Memenuhi persyaratan kurikulum dan bukanlah hal yang tidak sesuai, tetapi hanya yang terakhir yang dapat memberi makna kepada yang sebelumnya. Oleh karena itu, sebelum terlibat dalam kegiatan berbasis kurikulum, sekolah harus memulai 
DOI: 10.31004/obsesi.v5i1.573

proses pebelajaran dengan tidak memaksakan kurikulum yang tertinggal untuk di kejar "secepat kilat", oleh karena itu membangun ketahanan (resiliensi) pada anak dapat meminimalkan risiko trauma jangka panjang dari pandemi Covid-19.

\section{Intervensi untuk Manajemen Krisis Sekolah}

Dalam berbagai studi literatur yang di kumpulkan, terdapat beberapa intervensi kegiatan- yang dapat dilakukan ketika memulai kembali bersekolah (Capurso et al., 2020; Jimerson et al., 2015; Johnson \& Figley, 2012; Koplewicz \& Cloitre, 2016; L. A. Theodore, 2016), implementasi dalam intervensi ini dapat disesuaikan dan di modifikasi berdasarkan kreativitas dan pengetahuan yang dimiliki oleh guru taman kanak-kanak.

Tabel 1. Program Intervensi Kembali Bersekolah

\begin{tabular}{|c|c|c|c|}
\hline Tujuan & Aktivitas & Alasan & $\begin{array}{c}\text { Dimensi } \\
\text { Intervensi }\end{array}$ \\
\hline $\begin{array}{l}\text { Mendapatkan } \\
\text { kembali } \\
\text { kepercayaan dengan } \\
\text { teman sekolah dan } \\
\text { dengan ruang } \\
\text { sekolah. Menimbul } \\
\text { kan momen-momen } \\
\text { menyenangkan } \\
\text { terkait dengan } \\
\text { kehadiran di } \\
\text { sekolah }\end{array}$ & $\begin{array}{l}\text { 1. Sesi bermain Bebas, } \\
\text { Bermain di luar ruangan memiliki banyak } \\
\text { manfaat mengenai stres. Bermain } \\
\text { memungkinkan anak-anak untuk } \\
\text { menemukan bentuk ekspresi alamiahnya, } \\
\text { sebuah wadah di mana proses kognitif } \\
\text { dan afektif ditempatkan. Aktivitas } \\
\text { pertama yang harus dilakukan ketika } \\
\text { anak-anak memasuki kembali taman } \\
\text { kanak-kanak adalah membiarkan mereka } \\
\text { bermain dengan bebas. Hal tersebut akan } \\
\text { memungkinkan anak untuk } \\
\text { menyesuaikan kembali kenyamanan saat } \\
\text { berada di ruang sekolah, alat-alat } \\
\text { permainan kelas, dll }\end{array}$ & $\begin{array}{l}\text { Bermain adalah } \\
\text { komponen kunci } \\
\text { dari } \\
\text { perkembangan } \\
\text { masa kecil dan } \\
\text { dapat } \\
\text { mendukung } \\
\text { kemampuan } \\
\text { koping (Capurso } \\
\text { et al., 2020) }\end{array}$ & $\begin{array}{l}\text { Sosial, } \\
\text { emosional, } \\
\text { kreatifitas }\end{array}$ \\
\hline $\begin{array}{l}\text { Berpartisipasi } \\
\text { dalam kegiatan } \\
\text { eksplorasi } \\
\text { lingkungan untuk } \\
\text { mendapatkan } \\
\text { kembali } \\
\text { kenyamanan berada } \\
\text { di ruang sekolah. } \\
\text { Menumbuhkan } \\
\text { kesadaran anak- } \\
\text { anak tentang diri } \\
\text { mereka sendiri dan } \\
\text { orang lain di } \\
\text { lingkungan mereka. }\end{array}$ & $\begin{array}{l}\text { 2. Tour ruang sekolah yang dipandu } \\
\text { Anak-anak dibawa berkeliling ke } \\
\text { berbagai area di sekolah. Untuk setiap } \\
\text { ruang yang dituju, anak-anak diminta } \\
\text { untuk mengamati dan membuat daftar } \\
\text { berbagai benda yang menjadi ciri } \\
\text { khasnya. Guru menggunakan pertanyaan } \\
\text { menyelidik dan membantu anak-anak } \\
\text { megingat kembali aktiivitas } \\
\text { menyenangkan yang pernah dilakukan di } \\
\text { ruangan itu melalui memori yang telah } \\
\text { dimiliki anak. }\end{array}$ & $\begin{array}{l}\text { Anak-anak kecil } \\
\text { mengembangkan } \\
\text { perasaan diri } \\
\text { dalam waktu dan } \\
\text { ruang melalui } \\
\text { eksplorasi } \\
\text { lingkungan } \\
\text { (Johnson \& } \\
\text { Figley, 2012) }\end{array}$ & $\begin{array}{l}\text { Mengemban } \\
\text { gkan } \\
\text { kemampuan } \\
\text { spasial } \\
\text { anak; } \\
\text { mengemban } \\
\text { gkan } \\
\text { perasaan diri }\end{array}$ \\
\hline $\begin{array}{l}\text { Mengetahui bahwa } \\
\text { emosi yang berbeda } \\
\text { adalah bagian alami } \\
\text { dari diri. } \\
\text { Menyadari bahwa } \\
\text { anak-anak lain } \\
\text { hidup melalui jenis } \\
\text { peristiwa yang sama } \\
\text { dengan krisis } \\
\text { COVID-19. }\end{array}$ & $\begin{array}{l}\text { 3. Bagaimana perasaan saya di rumah? } \\
\text { fakta yang ada bahwa anak-anak harus } \\
\text { tinggal di rumah bersama orang tua } \\
\text { mereka dalam jwaktu } 24 \text { jam karena } \\
\text { keadaan darurat coronavirus. } \\
\text { Guru dapat membuat satu set kartu } \\
\text { perasaan dan meminta siswa untuk: } \\
\text { - mengenali emosi yang diwakili; } \\
\text { - Bercerita tentang aktivitas yang } \\
\text { dilakukan selama bersama orangtua } \\
\text { dirumah dan perasaan anak selama WFH } \\
\text { (work From Home) bersama orangtua. }\end{array}$ & $\begin{array}{l}\text { Untuk } \\
\text { memproses emosi } \\
\text { yang terhubung } \\
\text { dengan peristiwa- } \\
\text { peristiwa yang } \\
\text { membuat stres, } \\
\text { anak-anak harus } \\
\text { dapat } \\
\text { membaginya } \\
\text { dengan orang lain } \\
\text { dan dengan orang } \\
\text { dewasa dalam }\end{array}$ & $\begin{array}{l}\text { Pengenalan } \\
\text { emosi dan } \\
\text { pemrosesan } \\
\text { emosi }\end{array}$ \\
\hline
\end{tabular}




\begin{tabular}{|c|c|}
\hline Tujuan & Aktivitas \\
\hline & $\begin{array}{l}\text { Mengingat bahwa telah ada laporan } \\
\text { peningkatan insiden kekerasan dalam } \\
\text { rumah tangga selama isolasi pandemi, } \\
\text { guru harus menyadari fakta bahwa } \\
\text { anak-anak mungkin telah menyaksikan } \\
\text { atau menjadi korban kekerasan. Seperti } \\
\text { halnya kegiatan lain yang terhubung } \\
\text { dengan kehidupan keluarga, guru harus } \\
\text { memberi perhatian khusus pada tanda- } \\
\text { tanda potensi tekanan terkait kekerasan } \\
\text { pada anak. Sejalan dengan perundang- } \\
\text { undangan, guru harus siap untuk } \\
\text { menghubungi sekolah dan otoritas } \\
\text { sosial setempat jika ada tanda atau bukti } \\
\text { bahwa kekerasan tersebut terjadi. }\end{array}$ \\
\hline
\end{tabular}

Meningkatkan
kepercayaan kepada
orang dewasa yang
hadir di rumah
bersama keluarga
dan berbagi dengan
teman sekelas.

Perkuat pada anakanak suatu kesadaran akan kehadiran dalam hidup mereka dari figur-figur dewasa kunci yang dapat mereka andalkan.

\section{Anggota terpercaya dari keluarga anak}

Orang dewasa tepercaya dalam

kehidupan anak-anak adalah figur kunci

dalam proses emosional mereka dan merupakan faktor kunci yang membantu anak menyesuaikan diri dengan gangguan dalam kehidupan mereka. Guru meminta anak-anak untuk menyebutkan anggota keluarga yang membantu mereka dalam kehidupan sehari-hari atau yang menolong mereka menghadapi kesulitan. Para guru membimbing anak-anak untuk mengingat berbagai situasi yang berbeda (misalnya, ketakutan, rutinitas kehidupan seharihari, pekerjaan rumah, bermain dan bersenang-senang). Untuk merekap kegiatan, guru dapat membuat poster yang menunjukkan berbagai tokoh keluarga (ibu, ayah, kakek nenek, saudara kandung, paman, dll.) Dan letakkan di sebelahnya nama anak atau tanda yang mengidentifikasi mereka.

\section{Membuat referensi nyata untuk imajinasi anak-anak}

\section{5 . Gambarlah coronavirus.}

Anak-anak diminta untuk

membayangkan coronavirus dan menggambarnya.

Lembar aktivitas yang dibuat anak juga dapat digunakan untuk mengidentifikasi tipe mental seperti apa yang dimiliki anak-anak terhadap virus dan memberikan perspektif guru tentang bagaimana mereka memahaminya. Lembar kertas dan alat tulis lainnya tidak disediakan oleh guru tetapi dibawa sendiri ooleh anak

\section{Berbagi dan bertukar pikiran dengan orang lain memungkinkan

\author{
Emosional \\ dan \\ kognitif; \\ keluarga
} anak-anak untuk mengetahui berbagai cara mengatasi peristiwa dan menilai konsekuensi dari tanggapan yang berbeda (Jimerson et al., 2015; L. A. Theodore, 2016)j.
Dimensi Intervensi lingkungan yang

dapat

memberikan rasa

(L. A. Theodore,

2016) 
DOI: 10.31004/obsesi.v5i1.573

\begin{tabular}{|c|c|c|c|}
\hline Tujuan & Aktivitas & Alasan & $\begin{array}{c}\text { Dimensi } \\
\text { Intervensi }\end{array}$ \\
\hline $\begin{array}{l}\text { Membuat } \\
\text { pemikiran } \\
\text { antisipatif yang } \\
\text { positif dan } \\
\text { menghubungkan } \\
\text { kembali anak-anak } \\
\text { dengan komunitas } \\
\text { sekolah mereka. }\end{array}$ & $\begin{array}{l}\text { 6. Berdongeng, Kisah Asyik Saat di } \\
\text { Sekolah. } \\
\text { Kisah sekolah memberikan latar belakang } \\
\text { yang sama dan bertujuan memungkinkan } \\
\text { anak-anak untuk berhubungan kembali } \\
\text { dengan lingkungan dan satu sama } \\
\text { lain. Selain itu, cerita ini memunculkan } \\
\text { pemikiran antisipatif positif pada anak- } \\
\text { anak menuju masa depan. Cerita berakhir } \\
\text { dengan membuka pikiran anak-anak } \\
\text { terhadap keinginan mereka dan memberi } \\
\text { mereka kesempatan untuk } \\
\text { mengekspresikannya dan berbagi dengan } \\
\text { orang lain. }\end{array}$ & $\begin{array}{l}\text { Gunakan } \\
\text { metafora untuk } \\
\text { memproses } \\
\text { situasi saat ini } \\
\text { dan mengarahkan } \\
\text { perhatian untuk } \\
\text { fokus pada } \\
\text { pikiran positif } \\
\text { dan citra mental } \\
\text { (L. A. Theodore, } \\
\text { 2016) }\end{array}$ & $\begin{array}{l}\text { Emosional, } \\
\text { kreatif, } \\
\text { pikiran } \\
\text { positif }\end{array}$ \\
\hline $\begin{array}{l}\text { Menggunakan } \\
\text { strategi praktis } \\
\text { untuk mencegah } \\
\text { penularan. }\end{array}$ & $\begin{array}{l}\text { 7. Cuci tangan dan Gunakan Masker! } \\
\text { Mencuci tangan dan gunakan masker } \\
\text { adalah salah satu cara terbaik untuk } \\
\text { melindungi anak-anak dari sakit/ } \\
\text { penularan Virus. Mengajarkan kapan dan } \\
\text { bagaimana cara mencuci tangan dan } \\
\text { menggunakan masker yang benar adalah } \\
\text { kegiatan paling penting untuk tetap sehat } \\
\text { ditengah wabah Covid } 19\end{array}$ & $\begin{array}{l}\text { Mengajarkan } \\
\text { anak-anak untuk } \\
\text { berperilaku sehat } \\
\text { sejak dini } \\
\text { (Anhusadar \& } \\
\text { Islamiyah, 2021; } \\
\text { Capurso et al., } \\
\text { 2020) }\end{array}$ & Perilaku \\
\hline $\begin{array}{l}\text { Untuk memahami } \\
\text { apa itu kuman dan } \\
\text { menggunakan } \\
\text { sumber daya } \\
\text { kognitif untuk } \\
\text { memahami } \\
\text { dinamika dasar } \\
\text { kehidupan } \\
\text { mikrobiologis. }\end{array}$ & $\begin{array}{l}\text { 8. Video untuk mengetahui dan } \\
\text { memahami kuman/virus } \\
\text { Dalam minggu-minggu setelah masuk } \\
\text { kembali sekolah, dapat dirancang } \\
\text { perencanaan tentang pelajaran sains yang } \\
\text { membahas mikroorganisme. Anak-anak } \\
\text { dapat belajar tentang pandemi dengan } \\
\text { memahami kehidupan mikroba. } \\
\text { Untuk siswa taman kanak-kanak, dua } \\
\text { video dari chanel majalah bobo dan } \\
\text { KumparanMom memahami apa itu } \\
\text { kuman dan bagaimana penyebarannya: } \\
\text { Bagaimana Kuman Menyebar } \\
\text { Menjelaskan tentang Virus Corona } \\
\text { https://www.youtube.com/watch?v=Qx } \\
\text { CC1zlqzpE }\end{array}$ & $\begin{array}{l}\text { Anak-anak dapat } \\
\text { secara sosial } \\
\text { meningkatkan } \\
\text { pemahaman } \\
\text { mereka tentang } \\
\text { penyakit melalui } \\
\text { interaksi dengan } \\
\text { teman sebaya dan } \\
\text { kegiatan interaktif } \\
\text { sekolah (Capurso } \\
\text { et al., 2020) }\end{array}$ & Kognitif \\
\hline & $\begin{array}{l}\text { Hentikan Kuman Dari Penyebaran: } \\
\text { https://www.youtube.com/watch?v=ciR } \\
\text { wAED2mVs } \\
\text { Perlu diingat, berhati-hatilah untuk tidak } \\
\text { melebih-lebihkan pesan menakutkan } \\
\text { untuk mencegah peningkatan kegelisahan } \\
\text { di masa kanak-kanak. }\end{array}$ & & \\
\hline
\end{tabular}

Program intervensi merupakan suatu upaya yang dapat menjadi perhatian oleh semua pihak dalam menyiapkan anak kembali bersekolah dalam keadaan new normal agar anak memiliki kepercayaan dan kesukaan untuk bersekolah. Program intervensi memberikan dampak positif terhadap anak terutama anak yang paling beresiko dengan status sosial-ekonomi rendah. Guru memiliki peran penting dalam pengaturan kelas dan membawa siswa kembali ke kondisi pembelajaran normal. 


\section{SIMPULAN}

Penutupan sekolah memberikan dampak besar terhadap psikologi anak. Pada saat keadaan sudah kembali normal, kebutuhan anak untuk memproses peristiwa yang berkaitan dengan isolasi berkepanjangan yang disebabkan oleh pandemi COVID-19 akan sangat penting, dan menjadi masalah baru ketika hal tersebut tidak menjadi perhatian semua pihak. Strategi Koping dan membangun ketahan (resiliensi) pada anak adalah salah satu upaya dalam mengurangi dampak stres kepada anak. Program intervensi memberikan dampak positif kepada semua anak dan menjangkau anak yang termasuk kategori sosialekonomi yang lebih berisiko terdampak oleh covid 19 ini. Sekolah memiliki peran penting dalam pengaturan dan membawa siswa kembali ke susana pembelajaran normal.

\section{UCAPAN TERIMA KASIH}

Alhamdulillahirabbil'alamin, penulis bersyukur atas nikmat Allah SWT, sehingga dapat menyelesaikan penelitian kepustakaan ini. Saya sampaikan ucapan terimakasih kepada kampus IAIN Batusangkar tempat penulis mengabdi menjadi salah seorang dosen di Jurusan PIAUD, yang telah memfasilitasi dan mendukung sehingga penelitian ini dapat berjalan dengan baik. Semoga penelitian kepustakaan ini dapat memberikan manfaat pengetahuan tambahan bagi pemerhati, peneliti, peminat serta para praktisi pendidikan anak usia dini, Amin.

\section{DAFTAR PUSTAKA}

Abidah, A., Hidaayatullaah, H. N., Simamora, R. M., Fehabutar, D., \& Mutakinat, L. (2020). The Impact of Covid-19 to Indonesian Education and Its Relation to the Philosophy of " Merdeka Belajar ." Studies in Philosophy of Science and Education, 1(1), 38-49. https:// doi.org/https:// doi.org/10.15408/sjsbs.v7i3.15104

Agustin, M., Puspita, R. D., Nurinten, D., \& Nafiqoh, H. (2021). Tipikal Kendala Guru PAUD dalam Mengajar pada Masa Pandemi Covid 19 dan Implikasinya. Jurnal Obsesi : Jurnal Pendidikan Anak Usia Dini, 5(1), 334-345. https:/ / doi.org/10.31004/obsesi.v5i1.598

Anhusadar, L. O., \& Islamiyah. (2021). Jurnal Obsesi : Jurnal Pendidikan Anak Usia Dini. Jurnal Obsesi: Jurnal Pendidikan Anak Usia Dini, 5(1), 463-475. https:// doi.org/10.31004/obsesi.v5i1.555

Anwar, S. (2011). (2016). Metodologi Penelitian Bisnis. Salemba Empat.

Capurso, M., Dennis, J. L., Salmi, L. P., Parrino, C., \& Mazzeschi, C. (2020). Empowering Children Through School Re-Entry Activities After the COVID-19 Pandemic. Continuity in Education, 1(1), 64. https:/ / doi.org/10.5334/ cie.17

Chen, N., Zhou, M., Dong, X., Qu, J., Gong, F., Han, Y., Qiu, Y., Wang, J., Liu, Y., Wei, Y., Xia, J., Yu, T., Zhang, X., \& Zhang, L. (2020). Epidemiological and clinical characteristics of 99 cases of 2019 novel coronavirus pneumonia in Wuhan, China: a descriptive study. The Lancet, 395(10223), 507-513. https:/ / doi.org/10.1016/S0140-6736(20)30211-7

Compas, B. E., Jaser, S. S., Dunn, M. J., \& Rodriguez, E. M. (2012). Coping with Chronic Illness in Childhood and Adolescence. Annual Review of Clinical Psychology, 8(1), 455480. https:/ / doi.org/10.1146/annurev-clinpsy-032511-143108

Coyne, L. W., Gould, E. R., Grimaldi, M., Wilson, K. G., Baffuto, G., \& Biglan, A. (2020). First things first: Parent psychological flexibility and self-compassion during COVID-19. OsfPreprints, 5(4), 88-97. https:// doi.org/doi.org/10.31219/osf.io/pyge2

CSSE. (2020). Center for Systems Science and Engineering at Johns Hopkins University. (2020). COVID-19 https://gisanddata.maps.arcgis.com/apps/opsdashboard/index.html\#/bda7594740 fd40299423467b48e9ecf6

Dalton, L., Rapa, E., \& Stein, A. (2020). Protecting the psychological health of children through effective communication about COVID-19. The Lancet Child $\mathcal{E}$ Adolescent Health, 4(5), 346-347. https:/ / doi.org/10.1016/S2352-4642(20)30097-3 
DOI: 10.31004/obsesi.v5i1.573

Danandjaja, J. (2014). Metode Penelitian Kepustakaan. Antropologi Indonesia, 52. https://doi.org/10.7454/ai.v0i52.3318

Danese, A., Smith, P., Chitsabesan, P., \& Dubicka, B. (2020). Child and adolescent mental health amidst emergencies and disasters. The British Journal of Psychiatry, 216(3), 159162. https:// doi.org/10.1192/bjp.2019.244

de Kloet, E. R., \& Molendijk, M. L. (2016). Coping with the Forced Swim Stressor: Towards Understanding an Adaptive Mechanism. Neural Plasticity, 2016, 1-13. https:// doi.org/10.1155/2016/6503162

Dube, S. R., \& McGiboney, G. W. (2018). Education and learning in the context of childhood abuse, neglect and related stressor: The nexus of health and education. Child Abuse $\mathcal{E}$ Neglect, 75, 1-5. https:/ / doi.org/10.1016/j.chiabu.2017.09.029

Gugus Tugas Nasional, T. (2020). Berita Terkini, Data Sebaran Global dan Indonesia Kasus COVID 19. Gugus Tugas Percepatan Penanganan COVID-19. https://covid19.go.id/

Hong, H., Wang, Y., Chung, H.-T., \& Chen, C.-J. (2020). Clinical characteristics of novel coronavirus disease 2019 (COVID-19) in newborns, infants and children. Pediatrics $\mathcal{E}$ Neonatology, 61(2), 131-132. https:// doi.org/10.1016/j.pedneo.2020.03.001

Humphreys, K. L., Myint, M. T., \& Zeanah, C. H. (2020). Increased Risk for Family Violence During the COVID-19 Pandemic. Pediatrics, e20200982. https://doi.org/10.1542/peds.2020-0982

Jiao, W. Y., Wang, L. N., Liu, J., Fang, S. F., Jiao, F. Y., Pettoello-Mantovani, M., \& Somekh, E. (2020). Behavioral and Emotional Disorders in Children during the COVID-19 Epidemic. The Journal of Pediatrics, 221(2), 264-266.e1. https://doi.org/10.1016/j.jpeds.2020.03.013

Jimerson, S. R., Brock, S. E., \& Pletcher, S. W. (2015). An Integrated Model of School Crisis Preparedness and Intervention. School Psychology International, 26(3), 275-296. https://doi.org/10.1177/0143034305055974

Johnson, K., \& Figley, C. (2012). Trauma in the lives of children: Crisis and stress management techniques for counselors, teachers, and other professionals. Hunter House Publishers.

Koplewicz, H., \& Cloitre, M. (2016). Caring for kids after trauma, disaster and death: A guide for parents and professionals. New York University Child Study Center.

Lazarus, R. S., \& Folkman, S. (1984). Stress, appraisal, and coping. Springer Pub. Co.

Leger, K. A., Charles, S. T., Turiano, N. A., \& Almeida, D. M. (2016). Personality and stressorrelated affect. Journal of Personality and Social Psychology, 111(6), 917-928. https://doi.org/10.1037/pspp0000083

Leipold, B., \& Greve, W. (2009). Resilience: A conceptual bridge between coping and development. European Psychologist. European Psychologist, 14(1), 40-50. https://doi.org/10.1027/1016-9040.14.1.40

Lingiardi, V., \& McWilliams, N. (2017). Psychodynamic diagnostic manual, second edition: PDM2. Guilford Publications.

Liu, J. J., Bao, Y., Huang, X., Shi, J., \& Lu, L. (2020). Mental health considerations for children quarantined because of COVID-19. The Lancet Child \& Adolescent Health, 4(5), 347-349. https://doi.org/10.1016/S2352-4642(20)30096-1

Losoya, S., Eisenberg, N., \& Fabes, R. A. (2014). Developmental Issues in the Study of Coping. International Journal of Behavioral Development, 22(2), 287-313. https://doi.org/10.1080/016502598384388

Lumban Gaol, N. T. (2016). Teori Stres: Stimulus, Respons, dan Transaksional. Buletin Psikologi, 24(1), 1. https://doi.org/10.22146/bpsi.11224

Mailizar, M., Almanthari, A., Maulina, S., \& Bruce, S. (2020). Secondary School Mathematics Teachers' Views on E-learning Implementation Barriers during the COVID-19 Pandemic: The Case of Indonesia. Eurasia Journal of Mathematics, Science and Technology Education, 16(7), em1860. https:// doi.org/10.29333/ ejmste/8240

Masten, A., Herbers, J., Cutuli, J., \& Lafavor, T. (2018). Promoting Competence and Resilience 
DOI: $10.31004 /$ obsesi.v5i1.573

in the School Context. Professional School Counseling, 12(2), 76-84. https:// doi.org/10.5330/PSC.n.2010-12.76

Nasution, M. K. (2017). Penelaahan literatur. Teknik Penulisan Karya Ilmiah, 3. Sumatera utara. Researchgate. https:// doi.org/10.13140/RG.2.2.14333.26086

Nuraini, R. (2020). Kasus Covid-19 Pertama, Masyarakat Jangan Panik. Indonesia.Go.Id. https://indonesia.go.id/narasi/indonesia-dalam-angka/ekonomi/kasus-covid-19pertama-masyarakat-jangan-panik

Orgilés, M., Morales, A., Delvecchio, E., Mazzeschi, C., \& Espada, J. P. (2020). Immediate psychological effects of the COVID-19 quarantine in youth from Italy and Spain. PsyArXiv Preprints, 5(3), 56-66. https://doi.org/doi.org/10.31234/osf.io/5bpfz

Pedersen, S. F., \& Ho, Y.-C. (2020). SARS-CoV-2: a storm is raging. Journal of Clinical Investigation, 130(5), 2202-2205. https://doi.org/10.1172/JCI137647

Permatasari, A. N., Inten, D. N., Wiliani, \& Widiyanto, K. N. (2021). Keintiman Komunikasi Keluarga saat Social Distancing Pandemi Covid-19. Jurnal Obsesi : Jurnal Pendidikan Anak Usia Dini, 5(1), 346-359. https:/ / doi.org/10.31004/ obsesi.v5i1.577

Pisano, L., Galimi, D., \& Cerniglia, L. (2020). A qualitative report on exploratory data on the possible emotional/behavioral correlates of Covid-19 lockdown in 4-10 years children in Italy. PsyArXiv Preprints, 4(3), 34-46. https:// doi.org/https:// doi.org/10.31234/osf.io/stwbn

Prodjo, W. A. (2020). Mendikbud Nadiem Makarim Akan Umumkan Mekanisme dan Syarat Pembukaan Sekolah Minggu Depan. Kompas.Com. https://edukasi.kompas.com/read/2020/05/28/213933471/mendikbud-nadiemmakarim-akan-umumkan-mekanisme-dan-syarat-pembukaan-sekolah?page=all

Sandoval, J. (2013). Crisis Counseling, Intervention and Prevention in the Schools. Routledge. https:// doi.org/10.4324/9780203145852

Sari, D. A., Rahmita Nurul Mutmainah, I. Y., Astari Tarihoran, T., \& Bahfen, M. (2021). No Title. Jurnal Obsesi: Jurnal Pendidikan Anak Usia Dini, 5(1), 476-486. https:// doi.org/10.31004/obsesi.v5i1.548

Shaffer, D. R., \& Kipp, K. (n.d.). Developmental psychology: Childhood and adolescence. Cengage Learning.

Sudrajat, C. J., Agustin, M., Kurniati, L., \& Karsa, D. (2021). Strategi Kepala TK dalam Meningkatkan Mutu Pendidikan pada Masa Pandemi Covid 19. Jurnal Obsesi : Jurnal Pendidikan Anak Usia Dini, 5(1), 508-520. https:// doi.org/10.31004/obsesi.v5i1.582

Theodore, L. A. (2016). Handbook of Evidence-Based Interventions for Children and Adolescents (Lea A. Theodore (ed.)). Springer Publishing Company. https:// doi.org/10.1891/9780826127952

Tol, W. A., Komproe, I. H., Susanty, D., Jordans, M. J. D., Macy, R. D., \& De Jong, J. T. V. M. (2016). School-Based Mental Health Intervention for Children Affected by Political Violence in Indonesia. JAMA, 300(6), 655. https:// doi.org/10.1001/jama.300.6.655

UNESCO. (2020). Education emergencies. Retrieved March 28, 2020. https://en.unesco.org/themes/education-emergencies/coronavirus-school-closures

WHO. (2020). World Health Organization. Coronavirus disease (COVID-19) advice for the public. https://www.who.int/emergencies/diseases/novel-coronavirus-2019/advice-forpublic

Wiresti, R. D. (2021). Analisis Dampak Work From Home pada Anak Usia Dini di Masa Pandemi Covid-19. Jurnal Obsesi: Jurnal Pendidikan Anak Usia Dini, 5(1), 641653. https:// doi.org/10.31004/obsesi.v5i1.563 